\title{
Synchronization of B-scan diagnostic imaging with transducer position tracking for three-dimensional ultrasonic scanning
}

\author{
A. Sakalauskas ${ }^{1}$, R. Jurkonis ${ }^{1}$, A. Lukoševičius ${ }^{1}$ \\ ${ }^{1}$ Biomedical engineering institute at Kaunas University of Technology \\ Studentu str. 65, Kaunas LT-51359 Lithuania \\ Phone: +37037407119 \\ Email:sakalauskas.andrius@yahoo.com,rytis.jurkonis@ktu.lt,_arunas.lukosevicius@ktu.lt
}

\begin{abstract}
Diagnostic value of ultrasonic B-mode imaging is dependent on interpretation and competence of physician, because only information about single section of tissues volume is used for evaluation. 3D sonography systems for abdominal diagnostics are available, but such systems are not yet available in transcranial sonography and etc. One of possibilities to improve current diagnostic systems could be supplementing the 3D function, by combining a conventional B-mode system with a probe position tracking system. The aim of this study was to synchronize two sub-systems: the position tracker and the B-mode ultrasound apparatus for freehand threedimensional ultrasonic scanning and to evaluate supplementary 3D system estimating volume of the reconstructed 3D surface image of a tissue mimicking phantom of known dimensions.

The 3D scanning method was implemented by synchronous sampling of B-scan diagnostic images, linear position scanning with position tracking sensors. To evaluate experimentally our method we have used four units: ultrasound diagnostic B-scan system, three axis positioning system, electromagnetic position tracker and frame grabber. The 3D phantom of defined dimensions was laboratorymade from dental duplicating silicon. B-mode transducer positioning was deterministic, but time intervals between position changes where random simulating free-hand positioning. Synchronization of video sequence record with a position tracing was assured using the second channel of the position tracing system.

3D surface was reconstructed relating B-mode images to the position data. The volume of phantom calculated according to physical measurements of the caliper was assumed as a true value $V_{\text {true }}=47.054 \mathrm{ml}$. The estimated volume of a 3D model of a phantom was $V_{\text {model }}=46.87 \mathrm{ml}$. The estimated relative error of the volume was $0.4 \%$. We concluded that a common B-mode sonography diagnostic system could be extended for 3D functionality with the use of a two channel position tracing system without invasive reengineering, but more experiments should be done for approval.
\end{abstract}

Keywords: B-scan diagnostic system, position tracking, video to position synchronization, 3D rendering, surface reconstruction, volume estimation.

\section{Introduction}

Diagnostic ultrasound imaging is a widely used technique in a clinical practice. Two-dimensional ultrasonic scanning is mostly used for visualization of abdominal parts, hearth and for gynecological applications. The quality (contrast, resolution, signal-to-noise ratio) of acquired images is lower to compare with magnetic resonance imaging or computer tomography, but ultrasonic examination is quick to do, relatively cheap and nonassociated with radioactive exposure.

Planimetry is one of the main limitations of B-mode scanning. The measurements of structural changes of organs are mostly performed using a single cross-section of the volume of interest (VOI). However probably all parts of a human body or pathologies (for example tumors) have an irregular shape and this fact should be taken into consideration. This turns diagnostics based on experience of physician, who performs measurements of a region of interest (ROI) and such evaluation may be subjective. This shortcoming would be eliminated if the volume of the objects would be evaluated. Three-dimensional ultrasonic visualization could solve this problem.

Principle of three-dimensional ultrasonic scanning was proposed in 1956 [1], but the first ultrasonic threedimensional scanning system was implemented only in
1989 [2] due to limited capabilities of computation systems. Three-dimensional ultrasonic scanning is starting to be used in a clinical practice in the last decade. There are few ways to perform three-dimensional ultrasonic scanning: 1 - to use transducer with two-dimensional array, 2 - mechanical swept volume approach, 3 - freehand scanning approach [2]. Manufacturing of a probe with twodimensional array is technologically complicated, because a huge number of acoustic elements (at least 3000) requires the same number of electric channels. Also it is difficult to match the electric impedance of small acoustic elements. The mechanical swept volume approach uses a special precise mechanism inside the probe to sweep the plane of the B-scan through a VOI [2]. The main constraint of this method is that the size of the scanned volume is limited by the area of B-scan. The freehand scanning is performed using a positioning system, which is tracking the trajectory of the B-mode probe at the same time acquiring a set of B-scans, while a physician scans the VOI. These systems allow an arbitrary motion of the transducer [2]. The positioning system acquires information about the probe movements ( 6 degrees of freedom: three coordinates to describe position and three rotations to describe orientation). The transducer trajectory information is used for reconstruction of the volumetric image, because the position and orientation of all acquired B-scan planes are 
known. The freehand system is much cheaper to compare with other two described above. Our idea is to combine a positioning system and a conventional B-mode diagnostic system. The major task developing the freehand 3D ultrasound system is to calibrate two sub-systems: the position tracker and the B-mode ultrasound apparatus. These two systems must be synchronized in time and calibrated in space.

The aim of this study was to synchronize two subsystems: the position tracker and the B-mode ultrasound apparatus for the freehand three-dimensional ultrasonic scanning and to evaluate a supplementary 3D system estimating the volume of the reconstructed 3D surface image of tissue mimicking a phantom of known dimensions.

\section{Materials}

Experimental hardware was assembled from 5 main units. The ultrasound diagnostic B-scan system ATL 860I Imager was used for scanning (Advanced Technology Laboratories, USA). The center frequency of the transducer was $5 \mathrm{MHz}$, the angle of sector -85 degrees, the scanning depth was set to $95 \mathrm{~mm}$. The B-mode scanning transducer was with mechanically rotated piezoelement. The transducer front face was immersed into a distilled water bath. The dimensions of the bath where $70 \times 50 \times 40 \mathrm{~cm}$. The 3D phantom and reference dimensions array of reflectors where submerged and firmly fixed during scanning. The three axis positioning system (model EMS 301, scanning step size $0,2 \mathrm{~mm}$, maximum scaning length $\mathrm{X}-\mathrm{Y}-\mathrm{Z}$ 600$300-300 \mathrm{~mm}$ ) was produced by UAB ,Elintos matavimo sistemos" (Kaunas, Lithuania). The system is controlled from computer running our prepared program in the Labview environment. The systems USB interface was used for ASCII commands communication.

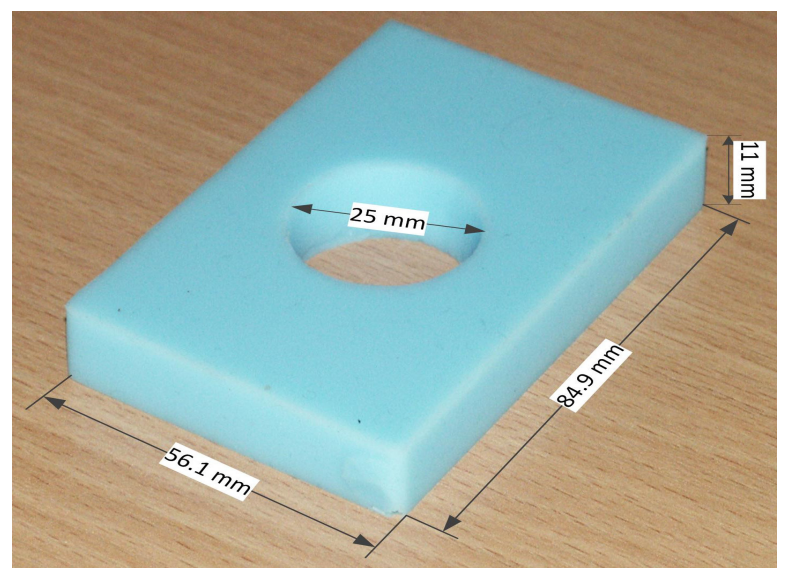

Fig.1. A phantom with size dimensions measured by caliper

The TrakSTAR 3D Guidance (Ascension Technology Corporation, USA) electromagnetic tracker designed for short-range motion tracking applications was used for a probe trajectory tracking. The TrakSTAR determines six degrees-of-freedom (6DOF) position and orientation (X, Y, Z, Azimuth, Elevation, and Roll) of the sensor referenced to a fixed transmitter. The static accuracy of tracking is 1.4 mm RMS for position, $0.5^{0} \mathrm{RMS}$ for orientation [3]. The position and orientation samples were acquired using 80 $\mathrm{Hz}$ rate.

The phantom of defined dimensions was made of dental duplicating silicon (density $\left.\rho=1.12 \mathrm{~g} / \mathrm{cm}^{3}\right)(\mathrm{N} \& \mathrm{~V}$, Belgium). The phantom dimensions were measured with a caliper tool after scanning procedure. The picture of phantom is shown in Fig. 1.

The B-scan system output video signal from a composite video terminal was connected to the external USB TV tuner AVerTV USB2.0 Plus (AVerMedia Technologies Inc., Taiwan), which recorded video sequences into a hard-disc of computer at 25 frames/s rate. The resolution of recorded video frames was $720 \times 560$ pixels.

\section{D data sampling}

We are approaching the 3D scanning method by synchronous sampling of B-scan diagnostic images, linear position scanning with position tracking sensors. For this purpose we were running three programs simultaneously on a single computer. Video sequence recording to a hard disk of the computer was done with the AVerMedia original software. The position tracking was performed also with an original software (Cubes). During scanning the phantom was fixed stable in a water bath (see Fig.2.). The B-scan transducer was fixed together with the position scanning sensor of the TrakSTAR system. The required deterministic positioning of the B-scan transducer (together with position sensor) was done with our prepared scanning software in the Labview programs environment. The Bscan transducer was fixed on arm of the positioning system together with the position sensor. The Labview virtual instrument was controlling scanning along a single axis with the constant step of $2 \mathrm{~mm}$. Therefore the B-mode transducer positioning was deterministic $2 \pm 0.2 \mathrm{~mm}$. In order to simulate the freehand positioning we intentionally did non-deterministic timing of position steps. The scanner virtual instrument was operated with user interrupt to allow each position step. So be time intervals between position changes randomly in interval from 0.5 to 2.0 seconds. Scanning of the B-mode transducer was done along the biggest dimension $(84.9 \mathrm{~mm})$ of phantom. To sample Bmode images of the whole phantom positioning was done in range $0-116 \mathrm{~mm}$.

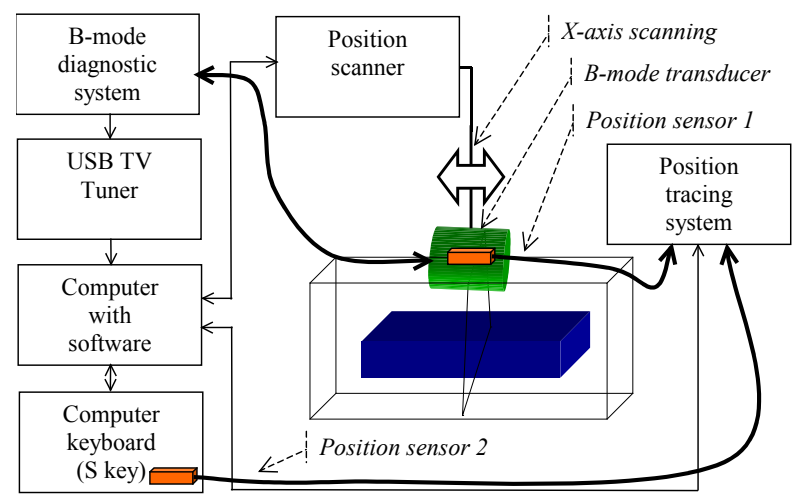

Fig. 2. Experimental setup structure to scan 3D phantom 
The sampling of 3D data was done running three software programs simultaneously on a single computer. First all programs were started and initialized for required parameters. The AverMedia software was started to record video sequences. The TrakStar position sampling was started as well. The Labview virtual scanner was started in a step-by-step user interrupted mode of operation. When 58 steps of position scanning were achieved the AverMedia software was stopped with use of keyboard input "Ctrl+S". The "S" key pressing was sensed with position sensor 2, therefore the second channel of the position sensing system was as trigger source for synchronization of sub-systems.

\section{Analysis of video sequence and position data}

Analysis of video sequences was done using standard MATLAB functions. The very last frame of the video sequence was in trigger with data of position tracking. Fig. 3 presents the relationship between the acquisition time and $X$ coordinate (the line marked by letter a), also between coordinate changes from the second trackSTAR channel (the line - c). The last frame was aligned to peak detected, then "S" key was pressed.

The acquisition duration was approximately 70 seconds. A huge amount of frames was obtained $(>1500)$. To operate with such amount of data is difficult respective to computation costs. Therefore the method for detection of a minimal number of frames which are necessary for 3D visualization of data was proposed. The position data were transformed using a squared differentiator in order to find the peaks of coordinate changes:

$$
y(t)=(\operatorname{diff}[x(t)])^{2},
$$

where $y(\mathrm{t})$ are the transformed $x(\mathrm{t})$ coordinates (Fig. 3., b), $x(\mathrm{t})$ - samples of $X$ coordinate, $t$ is the time. The exact instants of peaks were detected using a mowing-window step detector. The width of the time window was determined experimentally ( $\mathrm{w}=50$ samples). Since the instants of coordinate changes were known, the minimal number (58 frames) of frames were selected for 3D data analysis. These frames were selected taking a single frame from each detected interval between coordinate changes.

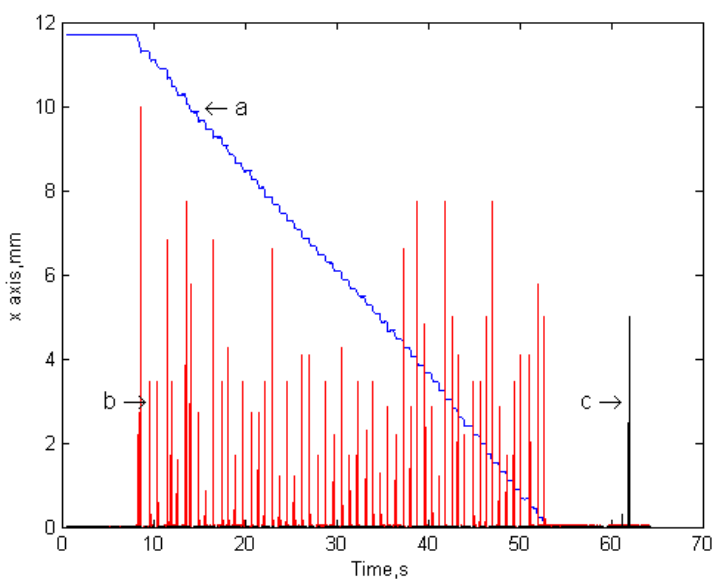

Fig.3. Relationship between acquisition time and $\mathbf{X}$ coordinate changes (line marked by letter a), line - b presents detected instants of coordinate changes, $c$ - coordinate change from the second channel of the positioning system which was used for synchronization.
All selected B-scans were analyzed visually and it was noticed that the shape of the scanned phantom is distorted. An example of a single B-scan is presented in Fig 4. It was found that these distortions result from a mismatch between the assumed speed of sound $c_{\text {assumed }}$, and the true $c_{\text {true }}$ speed in the silicone. For a B-scan system the average speed of ultrasound waves is permanently set to $c_{\text {assumed }}=1540 \mathrm{~m} / \mathrm{s}$ [4] by a manufacture. Speed of ultrasound waves in silicone was measured in order to eliminate geometry distortions. The speed estimation in silicon was made by insertion method, when the change of the time of flight was measured for two cases: just water and water with the inserted silicon. The insertion method was used with two transducers at the center frequency $3 \mathrm{MHz}$. The time delay difference of waves passing trough water and the silicon was found longer that for just water case. Knowing the thickness of silicon the speed was calculated to be 1092 $\mathrm{m} / \mathrm{s}$. From specification of the B-mode system we found that the sector of an ultrasonic image is formed from 128 rows, having 384 samples. The assumed steering angle of beam $\alpha_{\text {steered }}$ was also found and used for elimination of geometry distortions.

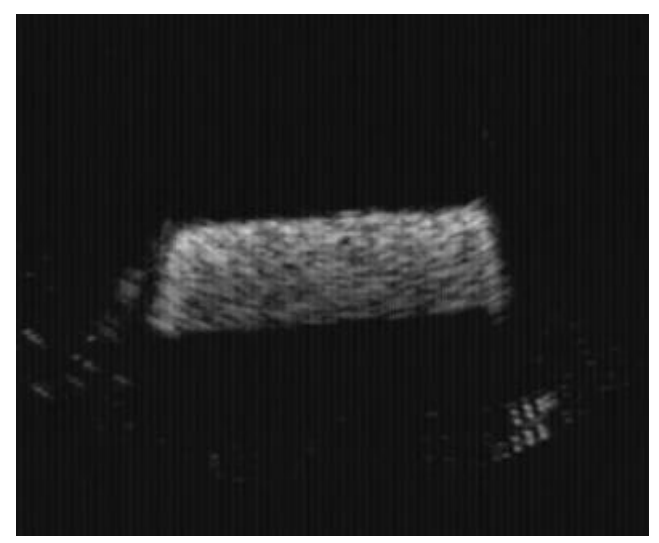

Fig.4. Single B-scan of a phantom

The true beam direction in the silicone when steering at angle $\alpha_{\text {steered }}$ is given by the Snell's law [5]:

$$
\sin \alpha_{\text {true }}=\frac{c_{\text {true }}}{c_{\text {assumed }}} \cdot \sin \alpha_{\text {steered }}
$$

The distance $r$ along any beam appears modified by the same ratio of speeds:

$$
r_{\text {true }}=\frac{c_{\text {true }}}{c_{\text {assumed }}} \cdot r_{\text {assumed }}
$$

Geometry distortions were eliminated using Eq. 1 and 2 in all obtained B-scans. An example of the B-scan after compensation of these distortions is shown in Fig. 5.

\section{D surface reconstruction and volume estimation}

All operations which were performed in order to reconstruct 3D surface image and to estimate the volume of a phantom are presented in Fig. 6 .

All selected B-scans were aligned in 3D space according to the scanning step $(2 \mathrm{~mm})$ and the pixel size in each B-scan $(0.33 \mathrm{~mm})$. Segmentation was performed using 


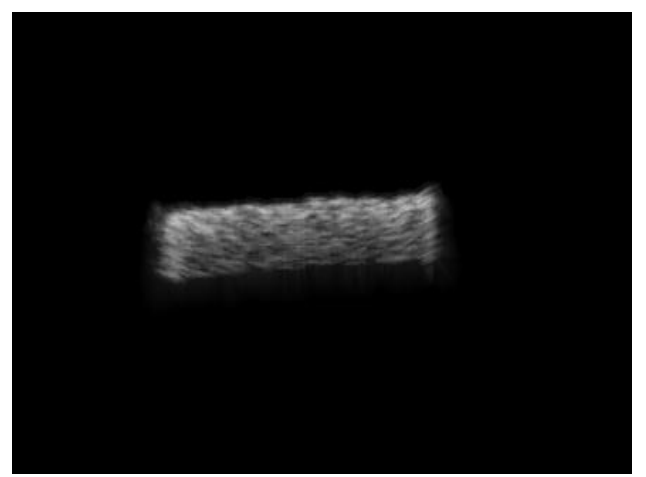

Fig.5. B-scan after compensation of geometry distortions due to sound speed difference (same B-scan as shown in Fig.4).

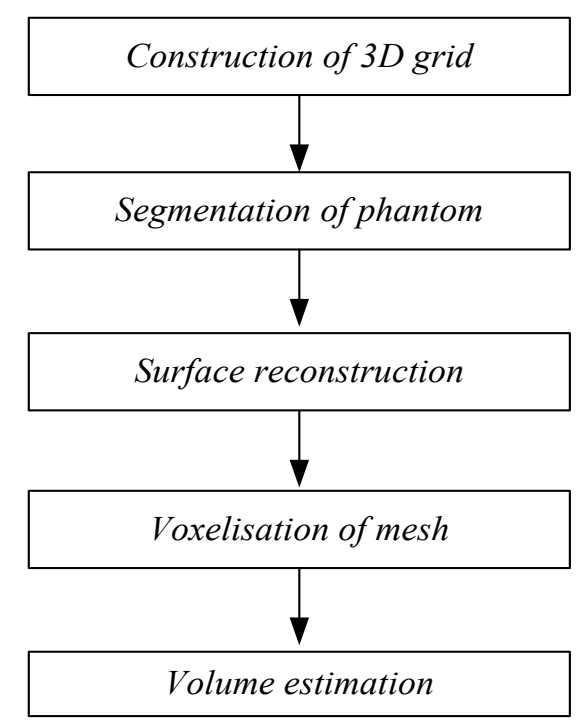

Fig.6. Algorithm for 3D surface reconstruction and volume estimation

a simple global thresholding algorithm. The threshold $\mathrm{T}>$ 0.3 (scale from 0 up to 1) for segmentation was determined during visual evaluation of a pixels lying near the boundaries of the phantom in obtained ultrasound B-scans.

Ultrasonic images are of a lower quality to compare with images obtained by computer tomography or magnetic resonance. The objects in ultrasound images contain missing or diffused boundaries due to a limited spatial resolution, speckle noise and other effects. Reconstruction of 3D surface of a phantom was performed in order to obtain uniform and smooth 3D model of a phantom [6, 7]. The MeshLab v. 1.3.1 (Visual Computing Lab - ISTI, Italia) free software [8] was used for a surface reconstruction. 3D surface image of a phantom was reconstructed using volumetric surface reconstruction algorithm, presented by [9], using default reconstruction parameters. All artifacts were removed and missing boundaries were closed during the reconstruction procedure.

The reconstructed uniform $3 \mathrm{D}$ mesh was converted to the volume assigning voxel intensity values inside the object to 1 , while to 0 outside. The size of a grid for voxelisation was determined regarding the size of a pixel in primary B-scans $(0.33 \mathrm{~mm})$. The volume of a 3D model was calculated by summing voxels which belongs to the volume:

$$
V_{\text {model }}=\sum_{i=1}^{N}(\Delta x \cdot \Delta y \cdot \Delta z), \quad \forall I_{i}(x, y, z)=1,
$$

where $V_{\text {model }}$ is the volume of $3 \mathrm{D}$ model, $\Delta x, \Delta y, \Delta z$ are dimensions of a single voxel, $N$ is the number of voxels belonging to the volume, $I$ is the voxel intensity value.

\section{Results}

The volume of the phantom calculated according to physical measurements of the caliper, was assumed as a true value $V_{\text {true }}=47.054 \mathrm{ml}$. Meanwhile the estimated volume of a $3 \mathrm{D}$ model of the phantom was $V_{\text {model }}=46.874$ $\mathrm{ml}$. The reconstructed 3D model of a phantom is presented in Fig 7. The estimated relative error of the volume was only $0.4 \%$, but it should be noticed, that only a single experiment was performed and the dimensions of a phantom which was used for experiments are relatively large.

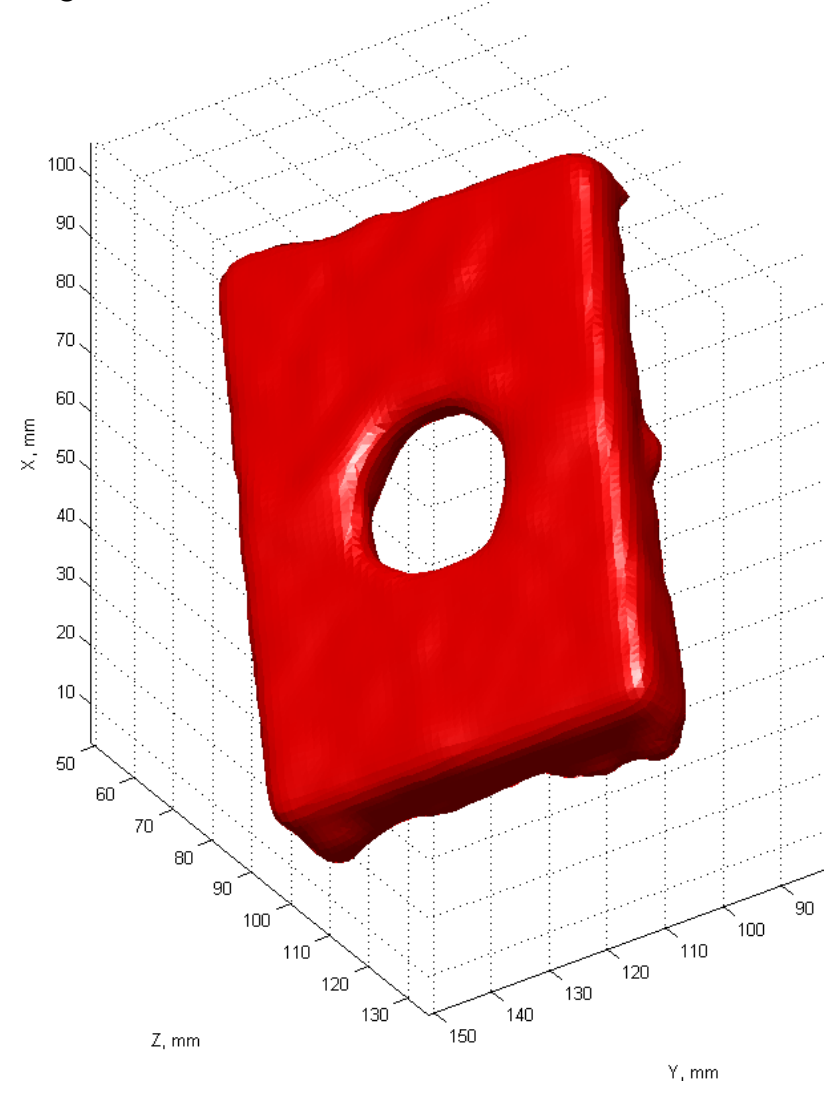

Fig.7. Reconstructed 3D surface image of a phantom

\section{Discussion}

We have evaluated the method of 3D data capturing with an ordinary B-scan system, a 3D position tracking system and a linear position scanning. The main goal was to evaluate the volume of a phantom in order to estimate feasibility of the method towards developing the free-hand 3D diagnostic ultrasound system. The position linear scanning was implemented for development, a free-hand 
scanning with position tracking would by the next step in development.

We have faced the problem of mismatch of speed of ultrasound using a laboratory-made 3D phantom. Our used B-mode diagnostic system had permanently set $1540 \mathrm{~m} / \mathrm{s}$ speed of ultrasound, but physically $1092 \mathrm{~m} / \mathrm{s}$ speed in silicone was measured. In imaging practice this mismatch causes large errors. For example, if we would not compensated B-scans images for a speed mismatch then the error of $3 \mathrm{D}$ reconstructed volume would increase up to $46.29 \%$ ( $\mathrm{V}=68.833 \mathrm{ml})$. This problem could also be fixed using a standardized 3D phantom for diagnostic system testing, however such 3D phantoms are expensive.

Also it was noticed that metallic objects lying near the transmitter of the positioning system affect accuracy of position tracking.

Experiments showed that it is possible to synchronize the ultrasound scanner with a two-channel position tracking system using our proposed method, but more experiments should be done for establishment of the proposed technique, scanning smaller and non-uniform objects. We concluded that a common B-mode sonography diagnostic system could be extended for 3D functionality with the use of a two channel position tracing system without invasive reengineering. More trials with our system and the known 3D phantom should be done with a free-hand positioning of a B-mode transducer to check if the proposed system and the method would function adequately without deterministic position scanning.

\section{Acknowledgements}

This work is sponsored by Research Council of Lithuania in the frame of National science program „Chronic non-infectious diseases” project "Application of transcranial ultrasound for diagnostic of neurodegenerative diseases", No.: LIG-28/2010.

\section{References}

1. Howry D., Posakony G., Cushman C. R., Holmes J. H. ThreeDimensional and Stereoscopic Observation of Body Structures by Ultrasound. Journal of Applied Physiology. 1956. Vol. 9(2). P. 304306.

2. Rohling R. N. 3D Freehand ultrasound: reconstruction and spatial compounding. Churchil college. A dissertation submitted to the University of Cambridge for the degree of Doctor. 1998. P. 4 - 88.

3. Ascension Technology Corporation. 3D Guidance trakSTAR: Installation and Operation Guide. 940037 Rev D 9/22/09.

4. Duck F. A. Physical Properties of Tissues (London: Academic Press Inc). 1990. P. 336.
5. Krucker J. F. and Fowlkes J. B. and Carson P. L. Sound speed estimation using ultrasound image registration. IEEE International Symposium on Biomedical Imaging Proceedings. 2002. P. 437-440.

6. Zhang Y., Rohling R. Direct Surface Extraction from 3D Freehand Ultrasound Images. The University of British Columbia. 2002. P. $45-52$.

7. Treece G. M. Volume measurement and surface visualization in sequential freehand 3D ultrasound. Christ's college, A dissertation submitted to the University of Cambridge for the degree of Doctor. 2000. P. 2 - 15.

8. MeshLab. Visual Computing Lab - ISTI -CNR, http://meshlab.sourceforge.net/.

9. Curless B. and Levoy M. A volumetric method for building complex models from range images. Proceedings of the 23rd annual conference on computer graphics and interactive techniques. 1996. P. 303-312.

A. Sakalauskas, R. Jurkonis, A. Lukoševičius

B režimo ultragarso įrenginio ir keitiklio pozicijos sekimo sistemos sinchronizacija trimatei echoskopijai atlikti

Reziumè

Darbo tikslas - ištirti galimybes sinchronizuoti ịprastinị B režimo ultragarso irengini su keitiklio pozicijos sekimo sistema trimatei ultragarsinei echoskopijai atlikti naudojant antruoju pozicijos sekimo sistemos kanalu gaunama informacija. Tikslui pasiekti buvo sujungtos keturios sistemos: 1) ultragarsinis B režimo skeneris; 2) elektromagnetinè pozicionavimo sistema; 3) mechaninės pozicionavimo staklès; 4) vaizdų perkèlimo modulis. Tyrimuose buvo naudojamas taisyklingas žinomų matmenų fantomas, pagamintas iš odontologijoje naudojamo silikono.

Bandymu metu ultragarsinis keitiklis buvo pritvirtintas prie pozicionavimo stakliu judančiosios dalies, kaip ir pozicijos sekimo sistemos jutiklis. Skenuojant tūrị plokštumų pozicijos buvo determinuotos (atliktas linijinis $2 \mathrm{~mm}$ žingsnio mechaninėmis pozicionavimo staklèmis valdomas skenavimas), bet laiko intervalai tarp skenavimo pozicijos pasikeitimo atsitiktiniai. Kartu buvo įrašinejjama vaizdo medžiaga. İrašinejiimas buvo stabdomas klaviatūros mygtuko, prie kurio pritvirtintas antrasis pozicionavimo sistemos jutiklis, paspaudimu. Sinchronizacija buvo atlikta sugretinus paskutini vaizdo įrašo kadrą su koordinačiu pokyčiu, užfiksuotu antruoju jutikliu. Kadrai, būtini 3D vaizdui gauti, buvo atrinkti analizuojant pozicionavimo sistemos informaciją iš pirmojo kanalo. Atrinkus reikiamus kadrus, buvo identifikuoti fantomo kontūrai $\mathrm{B}$ vaizduose ir atlikta fantomo trimačio paviršinio vaizdo rekonstrukcija.

Apskaičiuotasis rekonstruoto trimačio modelio tūris $-46,874 \mathrm{ml}$. Slankmačiu išmatuotas fantomo tūris - $47,054 \mathrm{ml}$, ir jis buvo traktuojamas kaip tikroji vertè. Santykiné paklaida siekè $0,4 \%$. Tai rodo, kad išbandytas metodas tinkamas sinchronizuoti B režimo ultragarso irengini su pozicijos sekimo sistema, bet norint tiksliau nustatyti metodo galimybes reikètų atlikti daugiau eksperimentų ir naudoti mažesnių matmenų, netaisyklingų formų fantomą

Pateikta spaudai 20111213 